\title{
PREPARATION OF TEACHERS OF TECHNICAL SUBJECTS IN THE FIELD OF OCCUPATIONAL SAFETY
}

\author{
Danka LUKÁČOV $\boldsymbol{A}^{*}$, Univerzita Konštantína Filozofa v Nitre, Slovenská \\ republika
}

Přijato: 9. 11. 2018 / Akceptováno: 12. 12. 2018

Typ článku: Teoretická studie

DOI: $10.5507 /$ jtie.2018.013

Abstract: Occupational safety and health protection affects all areas of human life and hence professional life too. A specific vocation in this respect is the teacher who has to master this issue with regard to his / her own safety and comfort and also to the comfort of the pupil. We investigated whether the study programs for technical subjects teachers at Slovak universities reflect this fact and how teachers are prepared in the field of occupational safety and health protection. Analysis of study plans and their comparisons show that not all students necessarily undergo graduate training in this field.

Key words: occupational safety, health protection, teachers, technology, study plans, analysis.

\section{PRÍPRAVA UČITELOV TECHNICKÝCH PREDMETOV V OBLASTI BEZPEČNOSTI PRÁCE}

Abstrakt: Bezpečnost’ práce a ochrana zdravia človeka zasahuje do všetkých oblastí l'udského života a teda aj do toho profesionálneho. Špecifickým povolaním $v$ tomto smere sú učitelia, ktori musia ovládat' túto problematiku vzhl'adom na vlastné bezpečie a komfort, a aj vzhl'adom na žiaka. Prieskumom sme zistovali, či študijné programy pre učitelov technických predmetov na slovenských univerzitách reflektujú túto skutočnost' a akým spôsobom sú učitelia pripravovani $v$ oblasti bezpečnosti práce a ochrany zdravia. Analýza študijných plánov a ich komparácia ukazujú, že nie všetci študenti v rámci pregraduálnej prípravy túto problematiku absolvujú.

Klíčová slova: bezpečnost' práce, ochrana zdravia, učitelia, technika, študijné plány, analýza.

\footnotetext{
*Autor pro korespondenci: dlukacova@ukf.sk
} 


\section{1 Úvod}

Právo na ochranu života a zdravia je základným právom človeka a je zakotvené v Ústave Slovenskej republiky. Kvalita ochrany pracovného života a zdravia občanov $\mathrm{v}$ širšom kontexte prezentuje kultúrnu, spoločenskú a ekonomickú vyspelost' spoločnosti.

Bezpečnost' práce zasahuje do všetkých oblastí profesionálneho l'udského života a predstavuje teda jeden zo základných kameňov odbornej prípravy na budúce povolanie a je jednou zo základných oblastí, ktorým je venovaná pozornost' v rámci legislatívy. Bezpečnost' a hygiena práce je tou sférou, ktorá sprevádza zamestnanca počas jeho produktívneho života a je teda tou oblast'ou, ktorá priamo vyžaduje celoživotné vzdelávanie (Serafín, 2016, s. 103).

Z tohto pohl'adu je možné predpokladat', že najmä učitelia na všetkých stupňoch škôl budú tými, ktorí v rámci svojho štúdia budú komplexne pripravovaní na poznanie väzieb medzi envirosystémom budov, komfortom, hygienou, bezpečnost'ou a spol'ahlivost'ou prostredia, ale tiež na poznanie odrazu škodlivín v zdraví a výkonnosti l'udí.

Výskumy potvrdzujú, že pohoda prostredia zvyšuje výkonnost' človeka cca o 2 - $4 \%$. Zvlášt' to platí pre prostredie, v ktorom charakter práce si vyžaduje myslenie, tvorivú činnost', sústredenost' a kreativitu. Medzi takéto prostredie patrí aj škola.

Ak poznáme faktory, ktoré ovplyvňujú pohodu a perceptibilitu človeka, môžeme vo výučbovom procese prijat' také opatrenia, aby boli zabezpečené optimálne podmienky na jeho výkonnost'. V rámci EU a aj vo svetovom meradle boli uskutočnené mnohé výskumy v oblasti vnútorného prostredia v školách, ktoré jednoznačne potvrdili, že v závislosti od stavby budov ich vnútorné prostredie ovplyvňuje nielen výsledky žiakov, ale aj ich zdravie. Preto je nevyhnutnost'ou, aby boli už v pregraduálnom štúdiu budúci učitelia vzdelávaní a pripravení na problémy bezpečnosti práce a ochrany zdravia človeka, tak, aby neskôr v praxi ako učitelia vedeli posúdit' kvalitu pracovného prostredia a optimalizovat' ju v prospech seba a svojich žiakov.

V kurikule základných škôl sa z pohl'adu skúmanej problematiky zdajú najdôležitejšími predmetmi, v ktorých učitelia otázky bezpečnosti práce a ochrany zdravia riešia prioritne technika, fyzika, chémia, telesná výchova. Predmet technika, vyučovaný na základných školách v SR, a predovšetkým jeho praktické časti, zohrávajú dôležitú úlohu v oblasti bezpečnosti a ochrane zdravia pri práci, ktorá zasa prispieva ku kvalitnejšej odbornej práci žiakov (Hrbáček, Kučerka, 2012).

Vzhl'adom na tieto úvahy sme sa rozhodli uskutočnit' prieskum študijných programov pre učitel'ov technických predmetov na základných školách v SR, s ciel'om zistit', či sú učitelia na univerzitách $\mathrm{v}$ pregraduálnom štúdiu naozaj konfrontovaní $\mathrm{s}$ otázkami bezpečného pracovného prostredia a ochranou zdravia človeka.

\section{Použité metódy a dosiahnuté výsledky}

Študijné programy so zameraním na výučbu technických predmetov sú akreditované podl'a portálu vysokých škôl na Univerzite Mateja Bela v Banskej Bystrici, Univerzite Konštantína Filozofa v Nitre a na Prešovskej Univerzite v Prešove. V prieskume sme sa preto sústredili na obsahovú analýzu študijných plánov týchto univerzít. V prieskume sme položili nasledovné prieskumné otázky:

1. Nachádza sa v študijnom pláne predmet zameraný na bezpečnost' práce a ochranu zdravia?

2. Kol'ko vyučovacích hodín v priebehu štúdia študent s týmto zameraním počas štúdia absolvuje v rámci prezenčnej výučby? 
3. Aké organizačné formy sú na výučbu používané?

4. Akým spôsobom sú hodnotené vedomosti a zručnosti študentov?

Predmetom prieskumu boli študijné plány týchto študijných programov:

- Učitel'stvo techniky v kombinácii predmetov na Univerzite Mateja Bela v Banskej Bystrici (UMB),

- Učitel'stvo techniky v kombinácii predmetov na Univerzite Konštantína Filozofa v Nitre (UKF),

- Učitel'stvo techniky na Univerzite Konštantína Filozofa v Nitre (UKF),

- Učitel'stvo techniky v kombinácii predmetov na Prešovskej univerzite v Prešove (PU),

Každý študijný program má bakalársky a magisterský stupeň. Každý stupeň štúdia, resp. jeho študijný plán a informačné listy predmetov sme skúmali samostatne. Výskumnou metódou bola obsahová analýza pedagogických dokumentov - študijných plánov a informačných listov predmetov. Spolu sme analyzovali osem študijných plánov.

Učitel'stvo techniky $v$ kombinácii predmetov (UMB)

$\mathrm{V}$ 1. stupni štúdia obsahuje študijný plán povinne volitel'ný predmet Legislatíva BOZP (bezpečnost' a ochrana zdravia pri práci). Po ukončení štúdia predmetu študent pozná: základné legislatívne predpisy pre oblast' $\mathrm{BOZP}$ a ich hierarchiu, rámcový obsah jednotlivých legislatívnych predpisov, povinnosti zamestnávatel’ov z pohl'adu BOZP, práva a povinnosti zamestnancov z pohl'adu BOZP, základné bezpečnostné a zdravotné požiadavky na pracovisko a pracovný prostriedok, dôvody bezpečnostného a zdravotného označenia na pracovisku, klasifikáciu a charakteristiku osobných ochranných pracovných prostriedkov, charakteristiku pracovných úrazov, chorôb z povolania, klasifikáciu zdrojov a príčin pracovných úrazov, kategorizáciu prác z pohl'adu rizika poškodenia zdravia (UMB, 2015). Rozsah výučby je $2 \mathrm{~h}$ prednášky a $1 \mathrm{~h}$ cvičenie za týždeň, v priebehu štúdia pišu študenti jednu seminárnu prácu a dve priebežné písomné práce. Ukončenie predmetu spočiva v písomnom teste a ústnej skúške.

V 2. stupni štúdia obsahuje študijný plán 18 predmetov, z ktorých jeden povinne volitel'ný predmet je orientovaný na pracovné prostredie (Pracovné prostredie). Rozsah výučby je $2 \mathrm{~h}$ prednášky a $1 \mathrm{~h}$ cvičenie za týždeň. Po ukončení štúdia predmetu je študent schopný charakterizovat' jednotlivé pojmy pre pracovné prostredie, zatriedit' faktory pracovného prostredia podl'a rôznych autorov, charakterizovat' a popísat' vybrané faktory pracovného prostredia - teplota vzduchu, vlhkost' vzduchu, rýchlost' prúdenia vzduchu, hluk, vibrácie, osvetlenie, žiarenie, nebezpečné chemické látky, prach, vírusy, baktérie, vybrat' vhodné meracie zariadenie a orientačne zmerat' hodnoty vybratých faktorov pracovného prostredia, popísat' škodlivé účinky jednotlivých faktorov pracovného prostredia na l'udský organizmus, vysvetlit' význam limitných hodnôt pre jednotlivé faktory v pracovnom prostredí, uviest' niekol'ko prípadov na elimináciu, prípadne redukciu škodlivých účinkov jednotlivých faktorov pracovného prostredia na zdravie l'udí, popísat' základné povinnosti zamestnávatel’ov a práva a povinnosti zamestnancov z pohl'adu vybratých faktorov pracovného prostredia (UMB, 2015). V priebehu štúdia študenti pišu dve seminárne práce, dve priebežné písomky a záverečné hodnotenie študenta sa vykoná na podklade písomnej a ústnej skúšky.

Učitel’stvo techniky v kombinácii predmetov (UKF)

V 1. stupni štúdia obsahuje študijný plán povinne volitel'ný predmet Bezpečnost' a hygiena práce. Predmet pozostáva z jednej hodiny prednášky a dvoch hodín cvičení za týždeň. Študent sa $\mathrm{v}$ rámci predmetu oboznámi so základnými hygienickými 
a bezpečnostnými požiadavkami na pracovisko. Po ukončení výučby pozná platnú legislatívu, vie ju aplikovat' pri hodnotení pracoviska. Pozná determinanty zdravia, definuje jednotlivé faktory pracovného prostredia. Vie uplatnit' získané vedomosti pri hodnotení kvality pracovného prostredia vybraných prevádzok. V priebehu štúdia študenti vypracujú jednu seminárnu prácu. Podmienkou úspešného absolvovania predmetu je úspešnost' v písomnom teste a na ústnej skúške (PF UKF, 2014).

\section{Ucitel'stvo techniky (UKF)}

Podobne ako v predchádzajúcom študijnom programe, na 1. stupni je do študijného plánu zaradený povinný predmet Bezpečnost' a hygiena práce $\mathrm{v}$ rozsahu 1 hodina prednáška a 2 hodiny cvičenie za týždeň. Predmet je ukončený skúškou a jeho obsah je totožný $\mathrm{s}$ rovnakým predmetom $\mathrm{v}$ študijnom programe Učitel'stvo techniky $\mathrm{v}$ kombinácii predmetov.

Ďalším povinným predmetom $z$ hodnotenej oblasti je predmet pracovné a životné prostredie ukončený priebežným hodnotením a vyučovaný v rozsahu 1 hodina prednáška a 1 hodina cvičenie za týždeň. Študent nadobudne terminologické vedomosti z pracovného prostredia a životného prostredia, porozumie rozdielom a previazanost'ou medzi životným pracovným prostredím. Naučí sa analyzovat' dôsledky antropogénnej činnosti na zdravie človeka v pracovnom procese a na environment. Po absolvovaní predmetu je schopný zhodnotit' nebezpečnost' technológií z hl'adiska pracovného a životného prostredia a dokáže implementovat' prvky systémov BOZP a životného prostredia do integrovaného systému riadenia. $V$ priebehu semestra študent vypracuje seminárnu prácu na zadanú tému a podrobí sa dvom písomným skúškam (PF UKF, 2014).

Učitel'stvo techniky $v$ kombinácii predmetov $(P U)$

Prešovská univerzita $\mathrm{v} 1$. stupni štúdia nemá zaradený predmet orientovaný na bezpečnost' práce a ochranu zdravia, $\mathrm{v}$ študijnom pláne pre 2 . stupeň štúdia je zaradený volitelný predmet Ergonómia a systematizácia pracoviska vyučovaný formou cvičení 1 hodinu za týždeň. Predmet je ukončený priebežným hodnotením, ktoré je hodnotením seminárnej práce vypracovanej na tému „Základné princípy a zásady vytvárania pracovných priestorov" a jej súčast'ou je projekt - návrh ergonomicky a systematicky usporiadaného pracovného priestoru. Seminárnu prácu študent prezentuje a obhajuje.

Po absolvovaní predmetu študent dokáže vysvetlit' význam ergonómie a systematizácie pracoviska špeciálnej edukácie, vlastnými slovami popísat' význam ergonómie pre špeciálnu pracovnú výchovu, interpretovat súlad technických a ergonomických požiadaviek pri vytváraní pracovného priestoru pre špeciálnu edukáciu, charakterizovat' a zdôvodnit' súvislosti medzi pracovným priestorom a zdravotne nezávodnou, kultúrnou a produktívnou prácou. Absolvovaním predmetu sa naučí vymenovat' a charakterizovat' parametre pre projektovanie pracovného priestoru, analyzovat' pracovný priestor $\mathrm{z}$ hl'adiska charakteru pracovnej činnosti, vybavenosti pracoviska a pohyblivosti pracoviska, organizácie práce, viazanosti pracovníka s pracoviskom, pracovnej polohy v kontexte potrieb špeciálnej edukácie (PU, 2015). Po ukončení predmetu by mal študent vediet' identifikovat' a popísat' problémy súvisiace s návrhom pracovného priestoru, vymenovat' a popísat' princípy ekonómie pracovných pohybov, vymenovat' a charakterizovat' jednotlivé etapy ergonomického riešenia. 


\begin{tabular}{|c|c|c|c|c|}
\hline & predmet & $\begin{array}{l}\text { počet } \\
\text { hodín }\end{array}$ & $\begin{array}{l}\text { organizačné } \\
\text { formy }\end{array}$ & hodnotenie \\
\hline \multirow{2}{*}{$\begin{array}{l}\text { Učitel'stvo } \\
\text { techniky } \\
\text { v kombinácii } \\
\text { predmetov } \\
\text { (UMB) }\end{array}$} & $\begin{array}{l}\text { Legislatíva } \\
\text { BOZP (PVP) }\end{array}$ & 3 & $\begin{array}{l}\text { prednáška } \\
\text { cvičenie }\end{array}$ & $\begin{array}{l}\text { písomný test } \\
\text { ústna skúška }\end{array}$ \\
\hline & $\begin{array}{l}\text { Pracovné } \\
\text { prostredie (PVP) }\end{array}$ & 3 & $\begin{array}{l}\text { prednáśka } \\
\text { cvičenie }\end{array}$ & $\begin{array}{l}\text { písomný test } \\
\text { ústna skúška }\end{array}$ \\
\hline $\begin{array}{l}\text { Učitel'stvo } \\
\text { techniky } \\
\text { v kombinácii } \\
\text { predmetov } \\
\text { (UKF) }\end{array}$ & $\begin{array}{l}\text { Bezpečnost' } \\
\text { a hygiena práce } \\
(\mathrm{PVP})\end{array}$ & 3 & $\begin{array}{l}\text { prednáška } \\
\text { cvičenie }\end{array}$ & $\begin{array}{l}\text { písomný test } \\
\text { ústna skúška }\end{array}$ \\
\hline \multirow[t]{2}{*}{$\begin{array}{l}\text { Učitel'stvo } \\
\text { techniky } \\
\text { (UKF) }\end{array}$} & $\begin{array}{l}\text { Bezpečnost' } \\
\text { a hygiena práce } \\
\text { (PP) }\end{array}$ & 3 & $\begin{array}{l}\text { prednáška } \\
\text { cvičenie }\end{array}$ & $\begin{array}{l}\text { písomný test } \\
\text { ústna skúška }\end{array}$ \\
\hline & $\begin{array}{l}\text { Pracovné } \\
\text { a životné } \\
\text { prostredie (PP) }\end{array}$ & 2 & $\begin{array}{l}\text { prednáška } \\
\text { cvičenie }\end{array}$ & $\begin{array}{l}\text { písomná } \\
\text { skúška } \\
\text { seminárna } \\
\text { práca }\end{array}$ \\
\hline $\begin{array}{l}\text { Učitel'stvo } \\
\text { techniky } \\
\text { v kombinácii } \\
\text { predmetov } \\
\text { (PU) }\end{array}$ & $\begin{array}{l}\text { Ergonómia } \\
\text { a systematizácia } \\
\text { pracoviska (VP) }\end{array}$ & 1 & cvičenie & $\begin{array}{l}\text { seminárna } \\
\text { práca }\end{array}$ \\
\hline
\end{tabular}

Tab. č. 1: Výsledky analýzy študijných plánov

\section{Diskusia a záver}

Porovnávané študijné plány obsahujú na 1 . alebo 2. stupni štúdia pre učitel’ov technických predmetov predmety zamerané na bezpečnost' a ochranu zdravia. Vo väčšine prípadov ide o povinne volitel'né, resp. volitel'né predmety, to znamená, že nie každý študent získa vedomosti uvedené $\mathrm{v}$ informačných listoch predmetov. Povinné predmety zamerané na skúmanú problematiku obsahuje iba študijný plán pre Učitel'stvo techniky, a to hned' dva: bezpečnost' a hygiena práce a pracovné a životné prostredie. Počty hodín, v ktorých univerzity pripravujú učitel'ov pre problematiku bezpečnej práce a bezpečné a príjemné pracovné prostredie sú vyrovnané, okrem študijného programu realizovaného na Prešovskej univerzite, kde celá problematika je zhrnutá do jednej hodiny cvičení týždenne. Podobnú vyrovnanost' vidíme v organizačných formách vyučovania, kde sa používajú prednášky a cvičenia (okrem už spomínanej Prešovskej univerzity). Zo šiestich skúmaných predmetov sú štyri ukončené písomnou aj ústnou skúškou, jeden predmet písomnou skúškou a seminárnou prácou a jeden predmet iba seminárnou prácou. 
V závere analýzy môžeme teda odpovedat' na položené otázky:

1. Vo všetkých štyroch skúmaných študijných programoch sa nachádza predmet zameraný na bezpečnost' práce a ochranu zdravia. Iba jeden študijný program obsahuje povinný predmet s týmto zameraním, ostatné predmety povinné nie sú.

2. Problematika bezpečnosti práce a ochrany zdravia je vyučovaná v rozsahu 1 - 3 hodiny týždenne, čo predstavuje 13 - 39 vyučovacích hodín za semester.

3. Na výučbu predmetov sú používané prednášky a cvičenia, $v$ jednom prípade iba cvičenie.

4. Predmety sú hodnotené na základe písomnej a ústnej skúšky, písomnej skúšky a seminárnej práce alebo iba seminárnej práce.

Študijné programy obsahujú v študijných plánoch predmety zamerané na oblast' bezpečnosti práce a ochranu zdravia, väčšinou sú to však predmety, ktoré nie sú povinné pre všetkých študentov. Viacerí výskumníci sa však zhodujú v tom, že v ideálnom prípade by všetci učitelia mali počas svojej profesijnej príprave a v neskoršej odbornej praxi absolvovat' základnú odbornú prípravu týkajúce sa BOZP a spôsobe začlenenia oblastí rizík do svojej praxe (Serafín, 2016, Beránek, 2009).

Článok je výsledkom riešenia projektu VEGA 1/0668/18.

\section{Literatura}

Akreditačný spis študijného programu Učitel'stvo techniky v kombinácii - bakalárske štúdium. (2014). Nitra: PF UKF. Interné materiály.

Akreditačný spis študijného programu Učitel'stvo techniky v kombinácii - magisterské štúdium. (2014). Nitra: PF UKF. Interné materiály.

Beránek, L. (2009). Information Systems Security Education for Future Teacher at Secondary and Primary Schools. In Journal of Technology and Information Education, 1(2). 89-93.

Hrbáček, J. \& Kučerka, M. (2012). Influence of Technical Education for Occupational Safety. In Journal of Technology and Information Education, 4(2). 57-59.

Serafín, Č. (2016). Current Access To Innovative Approaches Education in Occupational Safety and Health. In Journal of Technology and Information Education, 8(2). 93-104.

Študijný plán Učitel'stvo techniky v kombinácii predmetov. 1. stupeň. (2015). Banská Bystrica, UMB. Dostupné z: https://www.pdf.umb.sk/app/cmsSiteAttachment.ph p?ID=4046

Študijný plán Učitel'stvo techniky v kombinácii predmetov. 1. stupeň. (2015). Prešov: PU. Interné materiály.

Študijný plán Učitel'stvo techniky v kombinácii predmetov. 2. stupeň. (2015). Banská Bystrica, UMB. Dostupné z: https://www.fpv.umb.sk/app/cmsFile.php?disposition=a\&I $\mathrm{D}=19602$

Študijný plán Učitel'stvo techniky v kombinácii predmetov. 2. stupeň. (2015). Prešov: PU. Interné materiály. 